\title{
As luzes do século e as trevas da ignorância: intervenções da elite política e intelectual na formação dos cidadãos nas Minas Gerais regencial
}

\author{
Century lights and darkness of ignorance: interventions of the political and intellectual \\ elite in the formation of citizens in regency Minas Gerais
}

\author{
Júlia Lopes Viana Lazzarini \\ Doutoranda em História, UFRRJ \\ jllazzarini@gmail.com
}

\begin{abstract}
Resumo: A atuação de uma elite intelectual, que muitas vezes era também política, em relação ao alcance de suas ideias foi bastante considerável durante o período imperial. O período regencial trouxe consigo as discussões a respeito dos direitos políticos que deveriam ser cedidos a uma parcela da população brasileira, as quais se iniciaram após 1822. Algumas estratégias foram traçadas pelos poderes constituídos para contornar o problema quanto a presença das grandes massas e a ideia que se tinha sobre elas. No caso de Minas Gerais, a própria Assembleia Provincial dedicou lei que tornava obrigatória a frequência escolar dos cidadãos, possíveis futuros servidores da nação; o uso da imprensa também foi frequente, assim como a atuação dos párocos pode ter exercido papel fundamental para a disseminação dos ideais hegemônicas da elite política e intelectual vigente.
\end{abstract}

Palavras-chave: Elites, Minas Gerais, instrução popular.

\begin{abstract}
The work of an intellectual elite, which was often also political, in relation to the scope of their ideas was quite considerable during the imperial period. The regency period brought with it discussions about the political rights that should be given to a portion of the Brazilian population, discussions that started after 1822. Some strategies were outlined by the powers constituted to circumvent the problem regarding the presence of the great masses and the idea you had on them. In the case of Minas Gerais, the Provincial Assembly itself dedicated a law that made it compulsory for citizens to attend school and for possible future servants of the nation; the use of the press was also frequent, just as the role of parish priests may have played a fundamental role.
\end{abstract}

Keywords: Elites, Minas Gerais, popular instruction. 


\section{Introdução}

Por elite política entendemos desde indivíduos que ocupavam os cargos de maior destaque, incluindo os deputados, gerais ou provinciais, senadores, ministros, presidentes de província, conselheiros de Estado, até os cargos referentes ao poder local, como os de vereança. No que tange a elite intelectual podemos estender o quadro de possibilidades para indivíduos que fizeram parte do clero e também aos médicos, magistrados e demais bacharéis, assim como aos professores, editores e redatores de periódicos. Contudo, como intelectual não compreendemos simplesmente os que possuíam certo grau de escolaridade, mas os indivíduos que atuavam na sociedade por meio de uma pedagogia política normalmente expressa por meio dos periódicos. ${ }^{1}$ Muitos membros da elite intelectual fizeram parte do governo, mas nem todos que passaram pelos cargos públicos necessariamente foram membros de uma elite intelectual, muitos podem ter chegado a política por outros meios. Nada impedia que um membro da elite política e intelectual fizesse parte também de uma elite econômica. De certa forma, como apontaram Alcir Lenharo (1993: 99-100) e Wlamir Silva (2009: 104) ao observarem os políticos mineiros, grande parte da elite política e intelectual precisava ter acesso a riqueza para a promoção educacional.

Uma característica importante a ser destacada é que os redatores e editores de jornais muitas vezes foram membros de uma elite política, como bem observou José Murilo de Carvalho (CARVALHO, 2000: 141). Vejamos então as possibilidades que boa parte da elite política e intelectual possuía para se educar, desde as primeiras letras até a formação superior, e como ela se preocupou em estender seus valores ao povo, ou seja, a supostamente todos os cidadãos livres.

Em geral, partimos da ideia de que a elite intelectual, por vezes política e econômica, foi a principal agente responsável pelos projetos e tentativas de implementação de uma educação que atendesse às classes mais baixas. Fossem quais fossem seus reais objetivos, que podem supostamente variar entre a defesa e expansão das "luzes" e o uso da educação para "controlar" o grande número de pessoas

\footnotetext{
1 François-Xavier Guerra fez algumas considerações ao uso da imprensa na América espanhola no decorrer das lutas pela independência, ver GUERRA, François-Xavier (2000). Wlamir Silva (2009) fez importantes apontamentos acerca de uma pedagogia política liberal-moderada expressa pelos periódicos mineiros durante a primeira metade do período regencial. Aqui, buscamos levar em consideração tais observações feitas pelo autor.
} 
analfabetas que até então se viam entregues às "trevas da ignorância", a elite engajou parte de seus esforços em projetos e discursos à favor da educação popular.

Nosso objetivo é demonstrar o papel das elites no que tange à defesa da instrução popular durante o período das regências. A historiografia que se dedicou a estudar a dinâmica política e educacional na província de Minas Gerais já indicou o caminho e a lógica de pensamento da elite provincial, que sempre defendeu as "luzes" e a educação, mesmo que de forma elementar. Contudo, uma abordagem um pouco mais explícita sobre o assunto parece ser útil e necessária. Para este artigo buscamos observar a atuação política e intelectual das elites por meio do Universal, periódico liberal-moderado impresso em Ouro Preto entre os anos de 1825 e 1842, não somente por ser o jornal de maior periodicidade, mas também por se situar no centro dos debates políticos da província de Minas Gerais naquele período. Buscamos também considerar a inegável importância da participação dos clérigos no processo de formação política dos cidadãos. Para isso, iremos observar como a elite se educou e se formou e como esse tipo de educação influenciou nas maneira pelas quais interviram na educação popular.

\section{Educação e formação de uma elite política e intelectual}

Se as famílias com poucos recursos tinham de educar seus filhos na escola pública, ainda muito incipiente, isso quando o faziam, as famílias com maiores possibilidades e recursos iniciavam a formação de seus filhos por meio de professores particulares, liceus ou seminários. Enquanto na cidade do Rio de Janeiro se destacou o Colégio Pedro II, criado em 1838, no qual frequentavam os filhos das famílias ricas com pretensões ao ensino superior, em Minas, se destacou o ensino oferecido pelos padres lazaristas e vicentinos no Colégio do Caraça, instalado em 1820 (ANDRADE, 2013: 161-162). Tido como a primeira instituição privada em Minas Gerais, o Colégio do Caraça, segundo Mariza Guerra de Andrade, foi muito bem recebido pela elite oitocentista, que ansiava e necessitava de instituições para sua educação. A política de ensino do Caraça se centrava nas humanidades clássicas e direcionava sua grade curricular à vida pública, tendo como exemplo a magistratura e a vida eclesiástica e se destinando à determinados segmentos sociais (ANDRADE, 2013: 163-164). Para a 
autora, houve sinais de desconfiança por uma parcela da elite, existindo até mesmo certa perseguição com relação ao colégio durante os primeiros anos de sua fundação. A estabilização quanto ao funcionamento do Colégio do Caraça só se deu, finalmente, em 1856.

No que tange à educação superior da elite política e intelectual do Brasil, José Murilo de Carvalho aponta a política sistemática de Portugal quanto à proibição da criação de escolas de ensino superior em suas colônias, o que obrigava a elite a se formar em Portugal ou, em alguns casos, na França. A Universidade de Coimbra teve sua importância na formação da elite brasileira mesmo após 1822, oferecendo diplomados ao governo brasileiro até a década de 1850 (CARVALHO, 2013: 65). A série de reformas feitas pelo Marquês de Pombal na Universidade de Coimbra deu ênfase às ciências naturais, porém, após a queda de Pombal, em 1777, o Direito retomou sua predominância dentro da instituição, o que não deixou de influenciar a formação da elite política e intelectual atuante no Brasil (CARVALHO, 2013: 69).

As mudanças no quadro da educação superior no Brasil só se iniciaram após a vinda da família real portuguesa, em 1808, quando se criou a Real Academia dos Guardas-Marinha (1808) e a Academia Real Militar (1810), que antecedeu a Escola Militar. Fundou-se também duas Escolas de Medicina, uma no Rio de Janeiro (1813) e outra em Salvador (1815), a Academia de Belas Artes (1820), dois cursos de Direito, em São Paulo (1827) e em Olinda (1827) e a Escola de Farmácia (1839), em Ouro Preto. A Escola Naval, sucessora da Academia Real, era gratuita, o que por si só também não facilitava a entrada dos mais pobres, já que exigia "custosos enxovais" (CARVALHO, 2013: 74). Outras instituições de ensino, direcionadas para a carreira técnica, foram fundadas na segunda metade do XIX, como a Escola de Minas (1876) e a Escola Politécnica (1874), que segundo Carvalho podiam oferecer uma possibilidade de ingresso aos indivíduos com condições financeiras mais escassas (CARVALHO, 2013: 63-64). As faculdades de Direito e de Medicina cobravam taxas de matrícula, além de que os alunos de outras cidades ou de outras províncias tinham que se manter durante o curso, o que obviamente exigia investimento financeiro dos estudantes ou por parte da família dos mesmos.

Segundo Carvalho, os cursos de Direito oferecidos no Brasil tiveram suas adaptações em relação a formação coimbrã, como por exemplo as ênfases em conhecimentos sobre direito mercantil e marítimo e em economia política. Além disso, as faculdades de Direito buscavam formar não só juristas, mas também advogados, 
legisladores e diplomatas, indivíduos formados para ocuparem espaços de poder na sociedade (CARVALHO, 2013: 76).

Com isso, o autor indica que a elite política nacional normalmente possuía ensino superior. Dentre os ministros, a média de indivíduos com formação superior foi próxima à 90\% entre 1822-1889. Desses números, 70\% formaram-se em Direito, 16\% com formação militar e $3 \%$ com formação em Medicina. Se nos concentrarmos no período regencial vemos cerca de $85 \%$ dos ministros com formação superior, $56,67 \%$ em Direito, 13,33 com formação Militar, 6,66\% em medicina e 3,33 com uma formação religiosa (CARVALHO, 2013: 78-84). Segundo Carvalho, os dados para senadores e deputados não destoam muito do que vimos para os ministros, tendo altos e baixos em determinados períodos, mas mantendo uma média ao longo do império. A formação em Direito, juízes e advogados, predominou em todos os setores políticos mais relevantes, seguido pelos militares, médicos e clérigos.

Em Minas Gerais, Wlamir Silva afirma que muitos dos representantes políticos moderados tiveram origem na classe dos proprietários e "em torno dela se formou um grupo de não proprietários de especial catadura intelectual" (SILVA, 2009: 121). Esses indivíduos se destacavam como membros da elite política e intelectual, muitos deles sendo magistrados, clérigos e autodidatas que apareceram frequentemente e que, por sinal, atuaram ativamente quanto à formulação e organização do poder (SILVA, 2009: 123). Segundo Silva (2009: 123), parte dessa elite se utilizou da imprensa para disseminar seus projetos políticos e crenças, buscando atrair produtores agrícolas (grandes ou pequenos), comerciantes, assalariados, artesãos, militares e funcionários, ou seja, procurava-se atingir os cidadãos industriosos, aqueles que já se viam socialmente inseridos na sociedade mineira em contraponto aos marginalizados (os escravos e os "vadios"), estes últimos vistos como potencial perigo às causas liberais.

Dito isso, tudo parece indicar que todos aqueles que tiveram acesso à educação, que foram parte do governo ou que estiveram próximos do espaço público, foram marcados por experiências de vida que lhes inculcavam o preceito e a valorização das "luzes" em ambiente marcado pelo analfabetismo e pela inacessibilidade à educação, mesmo que básica. 


\section{A educação e a formação do clero, um caso à parte}

Apesar de muitos membros do clero terem feito parte de uma elite, se não econômica ao menos política ou intelectual, sua formação se deu de forma diversificada e não parece ter sido marcada pelo ensino superior. Aliás, o clero pode ter oferecido espaço para pessoas com menos recursos, mesmo que esses tivessem o auxílio de padrinhos. ${ }^{2}$ Dessa forma, cabe-nos perceber como essa parte formadora da elite política e intelectual se educou.

Segundo Françoise Souza (2010: 72-73), o rei, detentor do padroado, não se preocupou de forma considerável com a formação do clero em terras coloniais, dando maior atenção à expansão e manutenção das atividades mercantis e marítimas de Portugal, deixando nas mãos das ordens religiosas não somente a formação sacerdotal, mas também toda a educação oferecida na América portuguesa. A formação sacerdotal pela via da educação foi prevista no Concilio de Trento (1545-1563) e a partir de então os seminários passaram a ser o "sementeiro do clero", como uma instituição capaz de proteger e isolar o aspirante ao sacerdócio das más influências do mundo e promovendo um clero exemplar, intelectualmente e espiritualmente preparado para os seus deveres (SOUZA, 2010: 72).

Apesar das reformas tridentinas institucionalizadas no século XVI, os seminários só passaram a existir em terras brasileiras a partir de meados do século XVIII, recebendo pouquíssima ajuda financeira do Estado. Os seminários funcionavam como colégios, ou seja, além dos candidatos ao sacerdócio recebiam também alunos externos, muitos deles membros da elite abastada. Mas, no interior, principalmente nos locais de difícil acesso, o ensino e a aprendizagem, em geral, dependia muito mais da iniciativa familiar, que contratava seus próprios mestres e capelães, do que do Estado ou da Igreja (SOUZA, 2010: 72). Nessas localidades a formação sacerdotal também era difícil e por isso ficava à cargo do clero diocesano, que segundo Souza, "oferecia lições de latim, de teologia moral e de cerimônias litúrgicas", nesses casos os candidatos eram ordenados após serem examinados pelo bispo em uma de suas visitas pastorais (SOUZA, 2010: 72).

\footnotetext{
2 O mais comum era que pessoas com menos posses procurassem padrinhos de nível econômico superior ao seu para seus filhos. Há casos em que padres foram mantidos nos seminários por meio de seus padrinhos, como é o caso de José Antônio Marinho. Sobre apadrinhamentos em Minas Gerais ver BRÜGGER, Silvia Maria Jardim (2007). Sobre exemplos de padres "apadrinhados" ver SOUZA ,Françoise (2010).
} 
Contudo, cabe salientar que os jesuítas se destacavam quanto à cristianização dos indígenas e pelo direcionamento civilizatório das colônias portuguesas na medida em que figuravam como a principal referência religiosa e educacional, destacando-se também como os principais responsáveis pela formação do clero no Brasil (AZZI, 1977: 192). É interessante o destaque que Riolando Azzi dá à importância dos jesuítas quanto à formação do clero, inclusive do clero secular: "A Companhia de Jesus tinha uma estrutura mais aberta que lhe era proporcionada pelos colégios, fundados através de dotações régias. E os jesuítas abriam as portas desses educandários para que religiosos de outras ordens e seminaristas do clero secular pudessem aí completar seus estudos eclesiásticos". (AZZI, 1977: 192)

Apesar da importância da Companhia de Jesus nos âmbitos explicitados acima, os mesmos foram expulsos do império português pelo Marquês de Pombal em 1759, desembocando no fechamento ou na decadência dos seminários e colégios vinculados à Companhia de Jesus (AZZI, 1977: 192-200). Os poucos seminários que restaram, ligados à outras ordens, funcionavam muitas vezes de forma precária ou intermitente, alguns poucos foram fundados, como por exemplo o Seminário de Olinda. Com a decadência dos seminários, ou o menor número deles, a formação de alto nível do clero foi comprometida.

De acordo com Françoise Souza, a lacuna educacional deixada pelos jesuítas abriu espaço para a criação das aulas régias, sustentadas por um novo imposto e ministradas muitas vezes por membros do clero. Por meio das aulas régias uma pequena parte da população se preparava para os estudos na Europa ou para se ordenar sacerdote, sendo que os padres-mestres e os professores régios continuaram a ser uma opção para a formação eclesiástica (SOUZA, 2010: 74). Souza (2010: 74) afirma que diante das opções educacionais que o clero possuía, a maioria dos padres que se formaram ao longo do período colonial e em boa parte do século XIX, não passaram por seminários, não somente pelo baixíssimo número dessas instituições no Brasil como também pela falta da exigência de sua frequência para a ordenação, bastando exame de conhecimentos (que variavam de acordo com o nível: subdiáconos, diáconos ou presbíteros) e serem aprovados na diligência de sangue, vida e costumes.

A ordenação do clero brasileiro era pouco criteriosa, ao menos até se iniciarem as tentativas de reforma do clero, principalmente na década de 1850. Até então, os bispos de São Paulo, ao menos até a posse do bispo ultramontano D. Antônio Joaquim de Melo, receberam duras críticas de indivíduos que se opuseram no campo religioso 
e/ou político. D. Mateus de Abreu Pereira (1821-1824) e D. Manuel Joaquim Gonçalves de Andrade (1827-1847), ordenaram 111 e 231 sacerdotes respectivamente e foram acusados de não se preocuparem com as normas canônicas, ordenando indivíduos que não passaram por nenhum instituto de Filosofia e Teologia ou até mesmo sem nenhuma formação que passasse das primeiras letras (WERNET, 1987: 79-81 e HAUCK, 1992: 81-84). Desta forma, Augustin Wernet (1987: 80) afirma que mesmo em um período marcado por um "catolicismo iluminista" e de expressão pombalina, que teve predominância até meados do século XIX, nem todos os padres ordenados foram alcançados por tal formação. Porém, alguns bispos, ao menos pelos olhos do núncio de Roma, com uma visão um tanto quanto tendenciosa, parecem ter sido mais exigentes quanto à formação do clero que lhe era subordinado, como por exemplo os reformadores D. Romualdo Antônio de Seixas (1827-1860), arcebispo da Bahia, o bispo do Pará, D. Romualdo de Sousa Coelho (1819-1841) e o Bispo do Maranhão, D. Marcos Antônio de Sousa (1827-1842) (HAUCK, 1992: 82-83). Em Minas Gerais, cabe salientar que o bispado ficou sem seu bispo por nove anos, desde o falecimento, em 1835, do Frei José da Santíssima Trindade até a posse, em 1844, de D. Antônio Ferreira 204 Viçoso.

Apesar do fato do padroado português ter dado pouca margem, inclusive econômica, para a criação e manutenção de instituições próprias para a formação do clero e de que a maioria dos clérigos tenham se formado por meio de aulas régias, alguns padres conseguiram se ordenar nos poucos seminários existentes, como os de Mariana, São Paulo, Bahia, Paraíba, Maranhão, Pará ou Olinda, como foram os casos de várias figuras de destaque no cenário nacional. Outros tiveram sua formação promovida por Conventos do clero regular. Houve, em menor número, os que investiram numa formação superior, alguns foram à Europa, dando destaque novamente à Coimbra, outros se formaram no Brasil após a criação dos cursos jurídicos (SOUZA, 2010: 82).

Apesar das severas críticas quanto à formação do clero brasileiro, visto por alguns como pouco ilustrado e com costumes descordes com a moralidade e com a disciplina eclesiástica, vários pesquisadores, dentre eles José Murilo de Carvalho e Françoise Souza, concordam que em um contexto de analfabetismo qualquer tipo de educação, mesmo que elementar ou limitada, poderia ser um sinal de distinção. (CARVALHO, 2013: 182 e SOUZA, 2010: 75)

De acordo com Souza (2010: 91), os espaços de sociabilidade foram de grande importância para a formação político-intelectual de muitos setores da sociedade, 
inclusive dos padres-políticos, dando oportunidade aos que não obtiveram formação universitária a se informarem e de debaterem sobre as ideias do século. Nesse sentido, a autora aponta a importância da Maçonaria, vista como detentora de valores civilizacionais e como um centro de sociabilidade e de formação disposta em várias regiões do Brasil mesmo sua associação sendo proibida pelo Estado, de 1822 a 1831, e pela Igreja Católica desde 1738 (SOUZA, 2010: 93). Apesar de não haver nenhum registro da existência de lojas maçônicas em Minas Gerais durante o período regencial, alguns padres políticos tiveram acesso à maçonaria enquanto exerciam suas funções políticas na corte, como no caso dos padres Marcos Antônio Monteiro de Barros (senador e conselheiro provincial) e José Bento Leite Ferreira de Mello (deputado geral, senador, conselheiro provincial e fundador dos periódicos O Pregoeiro Constitucional e O Recopilador Mineiro), que também estiveram presentes em sociedades mineiras como a Sociedade Defensora da Liberdade e da Independência Nacional (LAZZARINI, 2020: $52-53)$.

O Instituto Histórico e Geográfico Brasileiro (IHGB) também teve seu destaque como local para a sociabilidade à partir de 1838, quando foi fundado. Segundo a autora, um outro espaço de sociabilidade em que os padres estiveram presentes foram as associações, dando destaque à Sociedade Defensora da Liberdade e da Independência Nacional (SOUZA, 2010: 100). Apesar da Sociedade Defensora inicialmente não se ligar diretamente e declaradamente a uma vertente política específica e abrigar diversos indivíduos com tendências políticas distintas (CASTRO, 1985: 13), após as ameaças de restauração por parte dos caramurus a Sociedade Defensora passa a ter como principal objetivo defender a nação contra essa ameaça, sendo claramente a favor do governo regencial de viés liberal-moderado (BASILE, 2004: 85).

A Defensora se estendeu por todo o Império, distribuindo grande prestígio social e político aos seus membros, mas obteve maior força eleitoral em Minas Gerais, São Paulo e Rio de Janeiro. Como expressão da importância da Sociedade Defensora, especificamente em Minas Gerais, vemos a associação de vários padres políticos, em grande medida influenciados pela atuação do grupo liberal-moderado que atuava na Defensora e que era encabeçado pelo padre mineiro José Bento Leite Ferreira de Melo. ${ }^{3}$ E é interessante, por fim, os números trazidos por Souza (2010: 103) no que tange ao grau de escolarização dos padres membros da Sociedade Defensora. Ao que parece,

\footnotetext{
${ }^{3}$ Para ficarmos somente com os padres deputados gerais de MG: José Bento Leite Ferreira de Melo, José Custódio Dias, Quadros Aranha, Antônio Maria de Moura.
} 
existia uma predominância de padres com diplomas universitários ou que concluíram o secundário em seminários ou colégios de Ordens regulares, havendo portanto a troca de conhecimento e socialização dos mesmos enquanto membros da Sociedade Defensora.

No que tange à origem social do clero brasileiro alguns autores apontaram para uma suposta diversificação bem maior se relacionada às demais camadas da elite política e intelectual durante o período colonial e persistindo por todo o império. Em Minas essa diversificação parece se confirmar, ao menos entre os padre-políticos que ali atuaram. Para entendermos os motivos para um certo grau de diversificação, precisamos levar em consideração alguns fatos: a) as poucas oportunidades de formação intelectual da população fez com que os indivíduos com pretensões de dar continuidade aos estudos e que não possuíam condições financeiras suficientes para se manterem em um curso superior vissem no sacerdócio uma chance de concretizar seu objetivo; b) as pretensões à cargos na administração pública não é descartada, podendo atrair sujeitos de várias camadas da sociedade; c) muitas famílias direcionavam um de seus filhos ao clero, não somente por questões religiosas mas também pelo prestigio, os filhos de militares, fazendeiros, comerciantes, agricultores e de profissionais liberais eram os que se aproximavam mais do clero, havendo algumas exceções a indivíduos de origem pobre, uma das exceções que é relatada com grande frequência é a do padre José Antônio Marinho, de origem modesta mas que caiu nas graças de um padrinho proprietário que o auxiliou. Diversos historiadores e alguns memorialistas chegaram a apontar para as origens sociais do padre Marinho, dentre eles Françoise Souza (2010), Alfredo Valadão (1974) e Sebastién Sisson (1999), este último observou tal especificidade ainda durante o século XIX, quando escreveu suas obras biográficas.

Levando esses pontos em consideração, mesmo que a carreira sacerdotal desse margem maior para a inserção de camadas médias da sociedade seus membros não emergiram diretamente de uma origem marcadamente popular, como aponta Souza (2010: 79). Além disso, exigiu-se certo nível financeiro para que candidatos ao sacerdócio não caíssem em ofícios vis para sobreviverem, assim como impossibilitavase a entrada ao clero, ao menos teoricamente, de indivíduos ligados a ofícios mecânicos, filhos ilegítimos e aos "mulatos". Quanto a exclusão dos "mulatos" e ilegítimos cremos não ter sido uma regra colocada em prática, o próprio padre regente Diogo Antônio Feijó era filho de "pais incógnitos" (RICCI, 2011), assim como o indicado ao bispado do Rio de janeiro, Antônio Maria de Moura. Além destes, houve diversos padres reconhecidamente pardos, como os padres mineiros José Custódio Dias e José Antônio 
Marinho, este último extremamente engajado na imprensa periódica mineira e na defesa da instrução.

Como membros de uma elite letrada, além dos aspectos religiosos provenientes da Igreja, os padres tiveram boas chances de se inserir no ambiente político, o que de fato ocorreu, sobretudo durante o período regencial. Vários padres ocuparam os espaços públicos, das páginas dos jornais ao parlamento brasileiro, dos púlpitos ao magistério, do âmbito provincial ao nacional, da santa religião ao secular. As possíveis influências do clero em relação a sociedade, inclusive sob os cidadãos pobres, são passíveis de observação, tanto por meio dos periódicos quanto, se não principalmente, por meio dos púlpitos e pela posição de poder exercida pelos mesmos. Para melhor compreendermos tal cenário cremos ser necessário levarmos em conta as condições educacionais dos cidadãos e a forma como a elite política e intelectual, inclusive muitos padres, os viam e, possivelmente, os atingiam.

\section{As tentativas de educação intelectual e de formação política do cidadão}

Ao longo do período imperial as preocupações acerca da promoção da instrução pública foram patentes, sendo motivo de discussão de projetos e reformas quanto às leis que impuseram a abertura de escolas públicas, gratuitas a todos os cidadãos brasileiros. Por meio da Constituição instituiu-se a todos os indivíduos livres o status de cidadão, ignorando-se a existência da enorme população escravizada (CARVALHO, 2008: 28). A Constituição de 1824, promoveu a institucionalização da instrução pública como direito dos cidadãos, sendo que em lei de outubro de 1827 determinou-se: a criação de escolas de primeiras letras em todas as cidades e vilas mais populosas; o ordenamento dos professores, tanto para homens quanto para mulheres; a modalidade de ensino mútuo passa a ser tida como padrão de ensino; funda-se também um currículo escolar, além de orientações para a abertura de instituições de ensino voltadas para meninas (VEIGA, 2013: 145).

Durante o período das Regências (1831-1840) houve descentralização do poder em função das províncias e a partir de 1835, após decisão imposta pelo Ato Adicional de 1834, as Assembleias Legislativas Provinciais passaram a vigorar, tomando para si o papel de legislar sobre a instrução primária (FARIA FILHO, 2013: 131). Em Minas Gerais, não demoraram os debates acerca de leis específicas sobre a instrução pública. 
Logo em 1835 fez-se a Lei $n^{\circ}$ 13, que segundo Luciano Mendes Faria Filho provavelmente possuía inspirações francesas, especificamente na "Lei Guizot", de 1833 (FARIA FILHO, 2013: 136-137). Dentre os artigos que a constituíram estavam mecanismos para a inspeção de escolas e de formação de professores, além da obrigatoriedade escolar. Ligava-se a obrigatoriedade escolar às penalidades para quem não matriculasse seus filhos na escola ou que não proporcionasse a instrução elementar por meio de instituição privada ou por ensino domiciliar. Além disso, houve a padronização da idade escolar, dos 8 aos 14 anos (FARIA FILHO, 2013: 137).

É possível notar, por meio do periódico O Universal, críticas relacionadas à baixa frequência escolar da população, mesmo antes da legislação que determinava a frequência escolar como obrigatória. Já em 1833, um indivíduo identificado somente por suas iniciais, J. J. S. A. ${ }^{4}$, apontou os supostos esforços da Assembleia e do Governo de Minas Gerais com relação a educação da juventude, que por sua vez, sofria com a "ambição com que certos pais de família ocupam seus filhos de serviços domésticos", não os provendo da educação e instrução "que a sociedade exige" (O Universal, Ouro Preto, 08/02/1833).

Apesar do governo da província de Minas estabelecer lei (1835) que obrigava a matrícula e a frequência das crianças nas escolas, a medida não obteve sucesso e o número de crianças matriculadas e frequentes eram ínfimos se comparados proporcionalmente a densidade populacional obtida nos censos. Segundo Faria Filho, havia em Minas, de acordo com o censo de 1833, cerca de 8 alunos frequentes para cada mil habitantes livres (FARIA FILHO, 2013: 141). Apesar das críticas da elite letrada, Veiga aponta como uma das causas para que muitos pais deixassem de matricular seus filhos nas escolas o fato de que não poderiam abrir mão do trabalho dos mesmos, tanto antes quanto depois da Lei $\mathrm{n}^{\circ} 13$; tal atitude poderia, após 1835 , ser passível de multa que variava, legalmente, entre 10 e 20 mil réis, por criança, e mesmo assim muitos pais não mandavam seus filhos à escola, correndo o risco de terem seus nomes expostos nas paredes das igrejas (VEIGA, 2013: 149). ${ }^{5}$ Segundo a autora, houve outros fatores, que combinados, impediam a frequência escolar: a pobreza da população, que muitas vezes

\footnotetext{
${ }^{4}$ Por se tratar somente das inicias, o processo de identificação fica comprometido, mas, nos permitimos arriscar que J. J. S. A. possa ser um dos vereadores liberais da Villa de São João Del Rei, o padre José Joaquim de Santa Anna. Que aliás, fez parte da Sociedade Defensora da Liberdade e da Independência Nacional, sediada em São João Del Rei.

5 As multas poderiam variar de dez a 20 mil réis, por criança, e mesmo assim muitos pais não mandavam seus filhos à escola, correndo o risco de serem multados e terem seus nomes pregados nas paredes das igrejas.
} 
não tinha nem mesmo vestuário; a dispersão populacional e das escolas; inconstância na administração; as limitações pedagógicas e, sobretudo, a "dissonância entre a expectativa de civilizar e o imaginário de uma população concebida como grupo inferior" pela elite (VEIGA, 2013: 150).

A crítica à infrequência escolar em contraponto a defesa da instrução por J. J. S. A. oferece-nos um ponto de vista interessante sobre as possibilidades de inserção dos sujeitos que conseguiam se instruir. Sobre a juventude que não frequentou o ensino por conta "da ambição" dos pais, J. J. S. A. completa: "Daí, vem que tais filhos chegam depois a ser pais de família e ignoram até os primeiros rudimentos da sua língua, não sabem ler, nem escrever, e sendo muitas vezes dotados de excelentes qualidades ficam inábeis para servir na Sociedade certos cargos, como por exemplo de Juízes de paz, de Vereadores, de Jurados etc.” (O Universal, Ouro Preto, 08/02/1833)

O autor do texto publicado no Universal, periódico liberal moderado impresso em Ouro Preto, afirmou que uma das formas do indivíduo se inserir ou "servir" a sociedade seria por meio da instrução, mesmo que rudimentar, recebida enquanto jovem. Sendo assim, podemos pensar que além da tentativa por parte da elite de minimizar as "paixões" da população analfabeta há também a tentativa de abrir oportunidade para que sujeitos com "excelentes qualidades" participassem da vida pública, ocupando diversos cargos. Não obstante essas expressões por parte dos letrados em relação a grande massa da população livre, o medo de possíveis consequências (revoltas, violência, escolhas políticas desacertadas, etc) foi uma preocupação manifestada pelos políticos do período.

Segundo Wlamir Silva, os escravos eram tidos em grande parte como perigosos, incapazes, infantis e viciosos, sempre sujeitos às influências de indivíduos mal intencionados (SILVA, 2009: 238). Vistos com desconfiança pelas elites na medida em que, devido as características dadas por sua condição, que de acordo com os liberais moderados tinham tendências ao vício e a desordem (SILVA, 2009: 235), poderiam servir como soldados para a "anarquia" por um lado, e por outro poderiam ser aliciados por facções absolutistas. Esse receio parece ter sido fortalecido pelo terror causado pela Revolução Haitiana que ainda assombrava a elite no Brasil (SILVA, 2009: 234-237). Marcos Ferreira de Andrade observou o "agenciamento" dos escravos por parte de 
brancos que levaria a revolta escrava de Carrancas em $1833 .{ }^{6} \mathrm{O}$ autor destaca o fato de que os senhores de escravos já indicavam temores relacionados a possíveis rebeliões coletivas de escravos (ANDRADE, 2014: 334 et seq.). Segundo Silva, o terror quanto à possibilidade do Brasil como um "novo Haiti" vinha da grande massa escrava existente no país, cerca de dois terços da população total. O medo da "maioria" era clara e o período regencial e suas turbulências parece ter atormentado também as "mentes moderadas" do período (SILVA, 2009: 234).

No que tange aos pardos - homens livres ou forros, podendo ser oriundos diretamente da escravidão ou por ascendência -, observa-se que ainda carregavam o estigma da escravidão e muitos deles viviam à margem da sociedade, não conseguindo usufruir integralmente dos canais de sociabilidade. Essa noção parece ser reafirmada por Ana Rosa Cloclet da Silva (2012: 142) na medida em que aponta o uso de expressões utilizadas pela elite, como "classes ínfimas", "povo rude” e "anárquica plebe", para se dirigir aos indivíduos marginalizados, "infinitos vadios, homens brancos, mestiços, pardos, cabras e crioulos forros”. É certo que muitos pardos, incluindo muitos libertos, fizeram parte de irmandades e fizeram delas seus canais de sociabilidade (SOUZA, 2010). No entanto, alguns deles conseguiram se integrar à sociedade por meio do contato com a elite ou até mesmo se tornando parte dela, fosse uma elite política, econômica ou intelectual. ${ }^{7}$ Esses pardos que conseguiram se inserir de alguma forma incorporados ao projeto liberal-moderado, que além de defenderem o "justo meio"8 que destacava os talentos, a instrução e a consciência liberal de seus pares “mestiços" (SILVA, 2009: 246-247). Porém, o mesmo não ocorreu com os pardos marginalizados, pobres e sem o apadrinhamento de ricos fazendeiros. Conforme nos mostra Wlamir Silva, os pardos marginalizados, pobres e mestiços, eram vistos pela elite política e letrada do período com desconfiança e medo; eram muito numerosos,

\footnotetext{
6 Ocorrida no ano de 1833 a revolta escrava de Carrancas envolveu a presença de escravizados de diversas fazendas da localidade, desembocando no assassinato de membros da elite daquela região dando estaque à família Junqueira. O caso pode ser visto de forma mais detalhada em ANDRADE, Marcos Ferreira de (2014).

7 É o caso do padre José Antônio Marinho, do também padre José Custódio Dias e de seu irmão, o capitão-mor Custódio José Dias.

${ }^{8}$ Os moderados que defendiam uma ideia de justo meio, se direcionavam pelos princípios da razão e da civilização. No Brasil, se defendia o "casamento" entre a Monarquia Constitucional e o Parlamento; defendia-se um Estado forte, mas não despótico. Outro ponto importante era a defesa dos direitos civis, apesar de não defenderem de forma alguma a igualdade social e a plena participação política por meio do sufrágio. Contudo, contradições ocorrem e merecem ser melhor observadas em trabalhos que se dedicaram e se estenderam com maior profundidade nas atuações políticas das diferentes facções que atuaram no período pós-independência e durante o período regencial. Ver MOREL, Marco (2016); BASILE, Marcello (2004); SILVA, Wlamir (2009).
} 
desprovidos de propriedades e visto como muito próximos, socialmente e moralmente, à escravidão (SILVA, 2009: 240).

É importante atentarmos para a noção de "razão" e de "ilustração" que vieram para o Brasil na bagagem do iluminismo e do liberalismo europeu, sendo extremamente valorizadas pela elite letrada brasileira e não menos pela elite política e intelectual mineira. A razão era vista como soberana e indispensável para o exercício da política, sendo pregada e exaltada pela imprensa do século XIX, que aliás era dirigida pela elite letrada e considerada "ilustrada" (MOREL, 2016: 92). Como consequência da exaltação da razão estava a negação e a crítica a tudo que pudesse parecer ou sugerir irracionalidade; a animalização aparece constantemente como recurso retórico para tal, o animalesco/selvagem contrastando-se à civilização (MOREL, 2016: 92).

Segundo Thaís Aguiar, a literatura do século XIX, dando destaque aos franceses, fez referências interessantes de serem observadas: as multidões eram normalmente relatadas com horror, análogas a "horda animal, à poderosa torrente, e a toda caracterização do submundo social vinculado ao alcoolismo, à promiscuidade, à loucura, e muitas vezes à criminalidade nas classes populares" (AGUIAR, 2015: 126). Nesse contexto de valorização da razão, após a proclamação da independência, em março de 1823 se instalou a Assembleia Constituinte que logo se viu fechada por D. Pedro I. Deputados foram presos e exilados e o imperador alegou haver perigo de "desunião" e de "anarquia" pregada por certa facção dominante que intimidava os deputados fiéis a ele. Como essa facção intimidava os outros deputados? Por meio da manipulação do "povo", que "armados de punhais e pistolas" incutiam o "terror" e amedrontavam os deputados (NEVES, 2011: 104).

Seguindo o mesmo sentido, a Sedição Militar de Ouro Preto, restauradora, iniciada em março de 1833 e finda em junho do mesmo ano, contou com a conivência de parte significativa dos habitantes ouro-pretanos e das localidades por onde suas ramificações se estenderam (SILVA, 2009: 287-289). Dentre os indivíduos que davam corpo a revolta estavam parte da elite de Ouro Preto, juízes de paz, militares de linha, alguns funcionários públicos, proprietários e comerciantes, mas também roceiros e homens pobres livres. O Universal, periódico liberal-moderado de Ouro Preto, acusou e condenou nominalmente muitos dos indivíduos que auxiliaram ou que por algum motivo foram coniventes aos sediciosos restauradores. Vejamos em uma passagem do Universal a descrição do redator: "aqueles mesmos que nas praças e nas ruas davam 
vivas aos caramurus, e celebravam a sua vitória, reconhecem hoje que foi tudo uma "cachaçada", e prossegue ao afirmar que:

Os encarregados de promover a sedição não perdiam ocasião alguma de incendiar os ânimos e de chamarem ao seus os descontentes, formando assim uma congregação dos Oficiais da Tropa da $1^{\text {a }}$ Linha, de alguns Empregados Públicos, e da mais gente, que perdida na opinião pública só buscava asilo no foco da perversidade. (O Universal, Ouro Preto, 05/06/1833)

Para além das críticas e acusações a pessoas de grupos específicos (empregados públicos, oficiais militares, alguns padres, políticos, juízes de paz, militares, etc), há também preocupações em relação ao que se chamou por gente "perdida na opinião pública", formada por pessoas que seguiram a torrente do "partido" caramuru. A forma de se inferiorizar o partido oposto ao governo situacional era afirmar que tudo aquilo não passou, no fim das contas, de "uma cachaçada", formada por "bêbados e ladrões" (O Universal, Ouro Preto, 27/05/1833). O que os liberais parecem apontar sobre o movimento é que este era predominantemente formado pela "tropa insubordinada e pelo povo amotinado" (O Universal, Ouro Preto, 03/07/1833), visto como "iludido" devido a sua falta de conhecimento, sendo facilmente manipulado pela oposição (O Universal, Ouro Preto, 16/09/1833).

É axiomática a forma como a elite letrada enxergava o povo, caracterizando-o como "multidão inconsciente", sujeito às "trevas da ignorância", ao "furor" e às "paixões". 9 Salta aos olhos a preocupação dos representantes mineiros, assim como da imprensa, quanto à instrução da população mais pobre como uma forma de se minimizar ou neutralizar as "paixões" das massas por meio da "civilização", ou seja, pela "ilustração". Além disso, o apelo ao povo quanto à escolha de bons representantes também se mostra, por vezes, por uma pedagogia política expressa pela elite letrada. Nesse sentido, mesmo que o processo eleitoral para deputação ainda não estivesse em curso, o periódico moderado considerou importante enumerar as qualidade de um "bom eleitor":

As qualidades pois, indispensáveis a um bom Eleitor, reduzem-se a que seja animado do amor do bem público, tenha uma madura circunspecção e seja

\footnotetext{
${ }^{9}$ Expressões usadas em várias edições do Universal, de Ouro Preto.
} 
dotado de uma integridade de consciência à toda prova: sendo porém estes dotes internos, conveniente é que se hajam feito conhecidos por ações externas, e neste caso somente a experiência, e uma experiência meditada, saberá dirigir com acerto as eleições dos eleitores, a fim de não serem frustrados, nem iludidos criminosamente os desejos e a vontade Nacional.

[...] Se o Eleitor não tiver probidade, para bem usar destes poderes, que sê-lhes transferem, com bem pouco escrúpulo trairá ele os seus outorgantes; e arredado da honra e da Lei, entregue a suas inclinações particulares, ou ao impulso de cegas e loucas paixões, bronzeando os ouvidos aos clamores do povo, e hospede às necessidades da Pátria, além passará as barreira do justo e falseará destarte a confiança Nacional. (O Universal, Ouro Preto, 25/02/1833)

Essa tentativa de educar o cidadão votante quanto à escolha dos eleitores, que de fato escolhem os deputados ${ }^{10}$, passa pela exaltação de qualidades morais dos possíveis eleitores, como "integridade", mas também passa por características e por capacidades racionais, por uma "experiência meditada", que não aja por meio de "paixões". A "louca paixão" vai de encontro as premissas da racionalidade, colocada no pedestal pela elite política do período, sobretudo pelos indivíduos influenciados pelos ideais liberais e iluministas.

A tentativa de se educar os votantes passa também pela tentativa de se neutralizar a população que passara a ter direitos políticos a pouquíssimo tempo. Neste ponto, é importante salientar que a instrução pública que se iniciou de forma mais controlada pelo governo provincial mineiro a partir de 1835, abrangia indivíduos dos 8 aos 14 anos. Portanto, é possível supor que quase toda a população pobre em idade para ser votante, acima de 21 anos, provavelmente era analfabeta, salvo possíveis exceções. Nestas circunstâncias, a elite ilustrada mineira agia por meio de um "mercado de pensamentos" que se preocupava em difundir as "luzes" por meio da imprensa (SILVA, 2009), e para tentar contornar o problema do analfabetismo as leituras em voz alta para aqueles que não sabiam ler poderia ser uma forma de transmitir as mensagens pretendidas (SILVA, 2009: 136-137).

${ }^{10}$ As eleições nesse período se deu em dois níveis. Primeiro, os cidadãos votantes (cidadãos que obedeciam os critérios censitários) escolhiam os eleitores, que finalmente escolhiam os representantes. Ver mais sobre o sistema eleitoral em SOUSA, Francisco Belisário Soares de (1979). 
Entretanto, uma outra maneira de se chegar ao povo são os discursos e sermões dos padres durantes as missas, festas religiosas e eleições. Também por esse motivo, os padres formavam uma importante parcela da elite política e intelectual naquele período, o que os faz merecer certo destaque neste artigo.

Era muito normal que o clero se envolvesse em assuntos políticos de várias ordens, tanto por meio da política oficial quanto por meio dos púlpitos. Segundo João Fagundes Hauck, o clero se destacava principalmente por meio da oratória, ocupando-se de forma acentuada com os assuntos políticos, sobretudo durante o período regencial (HAUCK, 1992: 86). Esse engajamento dos padres e frades em assuntos políticos poderia influenciar o povo, profundamente religioso. Muitos movimentos começaram ou se disseminaram por meio dos púlpitos, dentre eles podemos nomear a Revolução Pernambucana, conhecida também como Revolução dos padres; Confederação do Equador; Cabanada; e, segundo Hauck, até mesmo a Independência (HAUCK, 1992: 86). Se observarmos os exemplos externos ao Brasil veremos que o clero foi ativo também em outros locais. A França pode oferecer vários exemplos dessas participações durante a Revolução e nos anos que a procederam, ${ }^{11}$ e que inclusive influenciaram e estabeleceram ligações com membros do clero brasileiro (MOREL, 2017: 165).

Tentativas de direcionar as ovelhas ao "caminho correto" foram claras e podem ter chegado à população de forma mais efetiva, principalmente durante os Te Deuns, missas cantadas em ação de graças e em solenidades, que precediam as eleições paroquiais e durante as festas comemorativas. Por meio dos periódicos mineiros podemos ver como os padres exerciam sua oratória em função de suas crenças, religiosas e políticas. Vejamos o exemplo de um dos discursos proferidos pelo Padre Mestre José Antônio Marinho perante o colégio eleitoral de Ouro Preto, reunido em função da escolha de um deputado, em setembro de 1833, meses após a sedição promovida na capital da província pelos restauradores:

Se os escravos do Duque de Bragança encerrados e sitiados dentro destas montanhas, ufanavam-se de entregar as chamas e a pilhagem, as fortunas Públicas e particulares; se uma pequena fração dessa Tropa amotinada, saindo para fora da Capital ameaçava sem rebuço de morte à Pais de Família, Cidadãos pacíficos e autoridades constituídas; e derramaram o susto

\footnotetext{
11 Marco Morel (2017) procurou destacar a atuação dos abades De Pradt, Gregóire e Raynal durante o processo revolucionário francês e suas influências para as Américas.
} 
e a consternação no seio da Famílias daqueles cujo único crime era a lealdade ao Trono do Sr. D. Pedro II, e amor a Liberdade, obrigando-os a deixar suas casas para salvarem suas vidas e sua honra. Qual será, senhores Eleitores, a medida dos horrores e dos atentados no caso impossível da projetada restauração? Pesai, senhores. Eleitores, e julgai de quanta ponderação não é o ato que vamos praticar escolhendo um homem que pode com seu voto talvez apartar ou abreviar a aluvião de males que tememos. (O Universal, Ouro Preto, 09/07/1833)

O Padre José Antônio Marinho, como um dos pilares do liberalismo em Minas Gerais, deixa extremamente clara a sua aversão aos restauradores, "escravos do Duque de Bragança". O discurso proferido busca dar ênfase as atitudes dos restauradores, caramurus, durante a tomada de Ouro Preto e a deposição do Governo de Melo e Souza. De acordo com suas concepções políticas, Marinho busca mostrar os "horrores" e o "aluvião de males" causados pela "projetada restauração", sempre se dirigindo aos "senhores Eleitores". Prossigamos com a conclusão do discurso:

Ah! Senhores! É tempo de nos designarmos: os exemplos altamente clamam de todas as partes, e tome cada um o seu lugar; preencha cada um o seu dever: eu executo o meu, pregando-vos a verdade; vós executais o vosso, elegendo com os olhos em Deus um Deputado: para acertardes invocais de toda a vossa alma a sua Graça; ele jamais a recusa aos que de coração a imploram. (O Universal, Ouro Preto, 09/07/1833)

O padre liberal deixa claro que o seu dever é mostrar a verdade aos eleitores e para ajudá-los quanto à escolha acertada dos Deputados, recomendando, para isso, o auxílio de Deus. Ao que parece, na medida em que Marinho busca designar todos os males aos restauradores, tratados como "liberticidas" e "escravos do Duque de Bragança", e em contraponto, invoca a "graça" de Deus para auxiliar os Eleitores quanto à escolha de bons deputados, fica clara a relação de que os bons deputados não estão do lado dos restauradores. Supomos que por meio de sua influência enquanto membro da igreja há a possibilidade de que Marinho possa ter convencido ou sugerido aos Eleitores ouro-pretanos acerca de seus votos, mesmo que por simples exclusão de todos os restauradores. Além disso, fica clara também a tentativa do padre em educar os eleitores de acordo com suas crenças políticas, mas também religiosas. 


\section{Conclusão}

Sabe-se, por meio da historiografia, que a maioria da população no Brasil era analfabeta. $\mathrm{O}$ periódico liberal-moderado $\mathrm{O}$ Universal mostrou o que os membros da elite intelectual pensavam sobre as classes baixas, basicamente vistas como "sem luzes", regidas por supostas paixões e que podiam ser facilmente "iludidas". Sendo assim, a elite letrada, com maior destaque aqui a elite mineira, por meio da Assembleia Provincial e com apoio de outros membros da elite intelectual, inclusive por parte significativa do clero, passou por tentativas de educar os cidadãos nas primeiras letras; mas, não somente por meio das escolas se encaminharam as tentativas de se capacitar ou de se formar os cidadãos. Os púlpitos tiveram grande importância na medida em que os párocos tiveram contato regular e direto com a população. Os momentos que ofereceram maior abertura para a atuação política e pedagógica dos padres foram no decorrer dos processos eleitorais e durante as festas cívicas; vale destacar que o papel desempenhado pelos padres durante esses eventos eram legítimos, promovidos não somente pela igreja, mas também pelo Estado. ${ }^{12}$ Os jornais também não deixaram de se debruçar sobre a questão, sendo que muitos intelectuais buscaram contornar o problema do analfabetismo por meio da promoção de leituras em voz alta, disponíveis àqueles que se interessassem por elas.

\section{Fontes}

O Universal (1825-1842), Ouro Preto, Hemeroteca Digital da Biblioteca Nacional.

\section{Referências bibliográficas}

AGUIAR, Thais Florencio de (2015). Demofobia $e$ demofilia: dilemas da democratização. Rio de Janeiro: Azougue.

ANDRADE, Marcos Ferreira de (2014). Elites regionais e a formação do estado imperial: Minas Gerais - Campanha da Princesa (1799-1850). Belo Horizonte: Fino Traço.

ANDRADE, Mariza Guerra de (2013). Colégio do Caraça: a formação escolar e política das elites. In: RESENDE, Maria Efigênia Lage; VILLALTA, Luiz Carlos (orgs.). A Província de Minas, volume 2. Belo Horizonte: Autêntica Editora; Companhia do Tempo, pp. 161-180.

\footnotetext{
12 As leis eleitorais do primeiro reinado davam aos párocos amplos poderes, apesar das várias reformas ao longo do período imperial, os padres de paróquia continuaram a exercer forte influência durante as eleições, não somente por terem feito parte das mesas eleitorais por muito tempo, mas também pela obrigatoriedade de seus discursos e sermões no momento precedente as votações; tais discursos só foram abolidos pelas leis eleitorais em 1881. Sobre as leis eleitorais ver SOUZA, Francisco Belisário Soares de (1979). O sistema eleitoral no Império. Brasília: Senado Federal.
} 
AZZI, Riolando (1977). A instituição eclesiástica durante a primeira época colonial. In: HOORNAERT, Eduardo (coord.). História da Igreja no Brasil, Tomo II/1. Petrópoles: Vozes, Edições paulinas, pp. 155-244.

BASILE, Marcello O. N. C (2004). O Império em Construção: projetos de Brasil e ação política na corte regencial. Tese (Doutorado em História). Universidade Federal do Rio de Janeiro, Rio de Janeiro.

BRÜGGER, Silvia Maria Jardim (2007). Minas Patriarcal: Família e Sociedade (são João Del Rei - Séculos XVIII. São Paulo: Annablume.

CASTRO, Paulo Pereira de (1985). A experiência republicana (1831-1840). In: HOLANDA, Sérgio Buarque de (org). O Brasil Monárquico: dispersão e unidade. São Paulo: DIFEL, pp. 09-71.

CARVALHO, José Murilo de (2000) História intelectual no Brasil: a retórica como chave de leitura. IN: Topoi, Rio de Janeiro, $\mathrm{n}^{\circ}$ 1, pp. 123-152. Disponível em: $\quad$ https://www.scielo.br/scielo.php?script=sci_arttext\&pid=S2237101X2000000100123. Acesso: 11.mar.2020.

(2008). Cidadania no Brasil: o longo caminho. Rio de Janeiro: Civilização brasileira.

(2013). A construção da ordem: a elite política imperial. Teatro de Sombras: a política imperial. Rio de Janeiro: Civilização Brasileira, 2013.

FARIA FILHO, Luciano Mendes (2013). O Processo de escolarização na Província. In: RESENDE, Maria Efigênia Lage; VILLALTA, Luiz Carlos (orgs.). A Província de Minas, volume 2. Belo Horizonte: Autêntica Editora; Companhia do Tempo, pp.131-144.

GUERRA, François-Xavier (2000). Modernidad e independências: ensayos sobre las revoluciones hispânicas. México: FCE, MAPFRE.

HAUCK, João Fagundes (1992). A Igreja na Emancipação (1808-1840). In: História da Igreja no Brasil: Segunda Época, Tomo II/2. Petropoles: Vozes, pp. 07-140.

LAZZARINI, Júlia Lopes Viana (2020). O Clero para além do sagrado: atuação política dos padres, Minas Gerais, 1833-1837. Dissertação (Mestrado em História). Universidade Federal de São João Del Rei, São João Del Rei.

LENHARO, Alcir (1993). As tropas da moderação: O abastecimento da corte na formação política do Brasil, 1808-1840. Rio de Janeiro: Biblioteca Carioca.

MOREL, Marco (2016). As transformações dos espaços públicos: Imprensa, atores políticos e sociabilidades na cidade imperial (1820-1840). Jundiaí: Paco Editorial. (2017). A Revolução do Haiti e o Brasil escravista: o que não deve ser dito. Jundiaí: Paco Editorial.

NEVES, Lúcia Basto Pereira das (2011). A vida política. In: SCHWARCZ, L. M (dir.) História do Brasil nação: 1808-2010 - Crise Colonial e independência: 18081830. Rio de Janeiro: Objetiva, pp. 75-114.

RICCI, Magda (2011). Assombrações de um padre regente. Campinas: Editora da UNICAMP.

SISSON, S. A. (1999). Galeria dos brasileiros ilustres. Brasília: Senado Federal, vol. 2.

SILVA, Ana Rosa Coclet da (2012). O problema das "classes ínfimas" na nova ordem constitucional. Relações de poder, códigos de conduta e a construção do vocabulário político na província de Minas Gerais (1820-1831). Ariadna histórica. Lenguajes, conceptos, metáforas, 1 (2012), pp. 133-161, disponível em http://www.ehu.es/ojs/index.php/Ariadna

SILVA, Wlamir (2009). Liberais e povo: A construção da hegemonia liberal-moderada na província de Minas Gerais (1830-1834). São Paulo: HUCETEC. 
SOUZA, Françoise Jean O. (2010). Do Altar à Tribuna: os padres políticos no contexto de formação do Estado Nacional Brasileiro (1823-1841). Tese (Doutorado em História). Universidade do Estado do Rio de Janeiro, Rio de Janeiro.

SOUZA, Francisco Belisário Soares de (1979). O sistema eleitoral no império. Brasília: Senado Federal.

VALADÃO, Alfredo (1974). Vultos nacionais. Rio de Janeiro: Freitas Bastos.

VEIGA, Cynthia Greive (2013). Crianças pobres, negras e mestiças na organização da instrução elementar. In: RESENDE, Maria Efigênia Lage; VILLALTA, Luiz Carlos (orgs.). A Província de Minas, volume 2. Belo Horizonte: Autêntica Editora; Companhia do Tempo, pp. 145-160.

WERNET, Augustin (1987). A Igreja paulista no século XIX: A reforma de D. Antônio Joaquim de Melo (1851-1861). São Paulo: Editora Ática.

Artigo recebido em 12 de março de 2020.

Aprovado em 18 de novembro de 2020.

DOI: $10.12957 /$ intellectus.2020.49379 